\title{
The biological activity of the alcoholic and water extracts from late goldenrod (Solidago gigantea) on production of biomass by corn poppy (Papaver rhoeas)
}

\section{Aktywność biologiczna wyciągu alkoholowego i wodnego uzyskanego z nawłoci późnej (Solidago gigantea) na produkcję biomasy przez mak polny (Papaver rhoeas)}

\author{
Krzysztof Domaradzki ${ }^{1 *}$, Tomasz R. Sekutowski ${ }^{1}$, Anna Jezierska-Domaradzka ${ }^{2}$, \\ Adam Matkowski ${ }^{2}$, Anna Stochmal ${ }^{3}$
}

\begin{abstract}
Summary
The paper presents the results of the study evaluating biological activity of the alcoholic and water extracts from the late goldenrod (Solidago gigantea) on production of biomass by corn poppy (Papaver rhoeas). The water and alcoholic extracts (40\% and $80 \% \mathrm{MeOH}$ ) from underground and above ground plant parts were prepared under laboratory conditions. Working solutions of $5 \%$ and $10 \%$ were prepared from the extracts using distilled water as solvent and distilled water with the addition of adjuvant . The plants of corn poppy were sprayed with the examined solutions and then fresh mass produced by the plants was evaluated. The extracts dissolved only in the distilled water caused both inconsiderable stimulation and limitation of the biomass production by the corn poppy. The extracts dissolved in the water with the adjuvant addition showed much stronger stimulation of the corn poppy growth.
\end{abstract}

Key words: Solidago gigantea; Papaver rhoeas; alcoholic and water extracts; biological activity

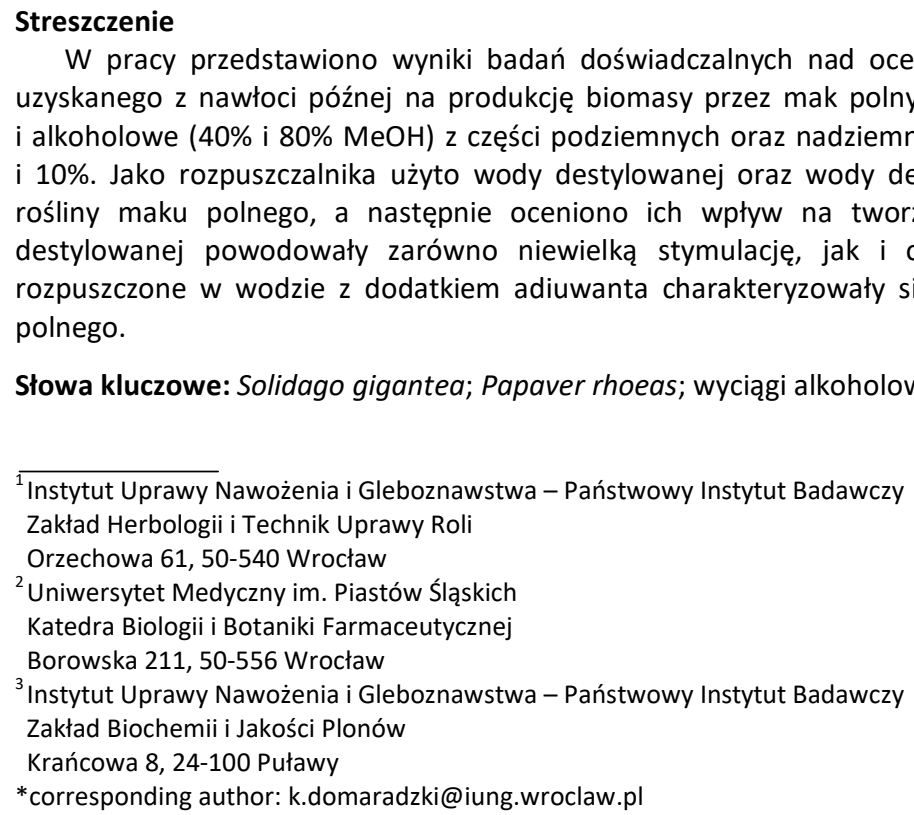
polnego.

\footnotetext{
${ }^{1}$ Instytut Uprawy Nawożenia i Gleboznawstwa - Państwowy Instytut Badawczy Zakład Herbologii i Technik Uprawy Roli

Orzechowa 61, 50-540 Wrocław

Katedra Biologii i Botaniki Farmaceutycznej

Borowska 211, 50-556 Wrocław

${ }^{3}$ Instytut Uprawy Nawożenia i Gleboznawstwa - Państwowy Instytut Badawczy

Zakład Biochemii i Jakości Plonów

Krańcowa 8, 24-100 Puławy
}

${ }^{2}$ Uniwersytet Medyczny im. Piastów Śląskich

*corresponding author: k.domaradzki@iung.wroclaw.pl

W pracy przedstawiono wyniki badań doświadczalnych nad oceną aktywności biologicznej wyciągu alkoholowego i wodnego uzyskanego z nawłoci późnej na produkcję biomasy przez mak polny. W warunkach laboratoryjnych przygotowano wyciągi wodne i alkoholowe (40\% i $80 \% \mathrm{MeOH}$ ) z części podziemnych oraz nadziemnych. Z wyciągów sporządzono roztwory robocze o stężeniu 5\% i $10 \%$. Jako rozpuszczalnika użyto wody destylowanej oraz wody destylowanej z dodatkiem adiuwanta. Roztworami opryskiwano rośliny maku polnego, a następnie oceniono ich wpływ na tworzenie świeżej masy. Wyciągi, które rozpuszczono w wodzie destylowanej powodowały zarówno niewielką stymulację, jak i ograniczenie produkcji biomasy przez mak polny. Ekstrakty rozpuszczone $w$ wodzie $z$ dodatkiem adiuwanta charakteryzowały się znacznie silniejszym działaniem stymulującym wzrost maku

Słowa kluczowe: Solidago gigantea; Papaver rhoeas; wyciągi alkoholowe i wodne; aktywność biologiczna 


\section{Wstęp / Introduction}

W Polsce występują 3 gatunki $\mathrm{z}$ rodzaju nawłoć (Solidago), które nie są gatunkami rodzimymi, a zostały sprowadzone z Ameryki Północnej. Są to: nawłoć późna (Solidago gigantea), nawłoć kanadyjska (Solidago canadensis) i nawłoć wąskolistna (Solidago graminifolia), które zaliczają się do antropofitów zadomowionych (Dajdok i Pawlaczyk 2009; Dajdok i Śliwiński 2009). Obecnie dwa z nich: nawłoć późna i nawłoć kanadyjska występują masowo w całym kraju, jedynie w części północno-wschodniej populacja tych gatunków jest zdecydowanie mniejsza (Tokarska-Guzik 2005; Rola i Rola 2010; Tokarska-Guzik i wsp. 2012). Tak silną ekspansję gatunki te zawdzięczają kilku czynnikom, a W szczególności intensywnemu wzrostowi, produkcji dużej liczby nasion, mikoryzie arbuskularnej oraz produkcji związków allelochemicznych wydzielanych do gleby i oddziaływujących inhibicyjnie na mikroflorę glebową oraz na inne rośliny (Yang i wsp. 2007; Abilasha i wsp. 2008; Zhang i wsp. 2009; Tang i wsp. 2009).

Na temat allelozwiązków wydzielonych do gleby przez różne gatunki donorowe - $\mathrm{w}$ tym również i nawłoć a oddziałujących inhibicyjnie lub stymulująco na kiełkowanie nasion innych gatunków roślin (akceptory), pojawiło się już wiele prac naukowych (Putnam 1988; Anwar i wsp. 2003; Khan i wsp. 2005; Pisula i Meiners 2010). Mniej natomiast jest artykułów dotyczących inhibicyjnego lub stymulującego działania wyciągów alkoholowych czy wodnych sporządzanych ze świeżych bądź suszonych liści i łodyg lub korzeni i kłączy donora i aplikowanych nalistnie na rośliny akceptora (Bing-Yao i wsp. 2006; Kieć i Wieczorek 2009; Sekutowski i wsp. 2012; Baličević i wsp. 2015). Taki kierunek badań jest rozwijany w Azji, głównie w Indiach, Pakistanie i Chinach (Cheng i Cheng 2015). W badaniach tych przeważają oceny możliwości stosowania allelopatyn jako naturalnych herbicydów, choć również rozważane są możliwości użycia tych związków do stymulacji wzrostu roślin (Cheema i wsp. 2013).

Celem przeprowadzonych badań była ocena aktywności działania wyciągów alkoholowych i wodnych, uzyskanych z części nadziemnych i podziemnych nawłoci późnej (S. gigantea) w odniesieniu do produktywności świeżej masy maku polnego (Papaver rhoeas).

\section{Materiały i metody / Materials and methods}

\section{Materiał roślinny do badań}

Materiał roślinny do uzyskania ekstraktów zebrano $\mathrm{z}$ roślin rosnących $\mathrm{w}$ warunkach naturalnych na terenach odłogowanych w miejscowości Wały, powiat Wołów, województwo dolnośląskie. Rośliny zbierano po zakończeniu wzrostu elongacyjnego pędu w fazie BBCH 39, a pozyskany materiał podzielono na części nadziemne (łodyga i liście) oraz podziemne (korzenie i kłącza). Zebrany materiał wysuszono na wolnym powietrzu, uzyskując powietrznie suchą masę. Tak wysuszone korzenie i kłącza oraz pędy i liście zostały osobno dokładnie zmielone do uzyskania dobrze rozdrobnionego materiału, pozbawionego większych fragmentów.

\section{Ekstrakcja substancji biologicznie czynnych}

Zmielony susz poddano ekstrakcji ciśnieniowej za pomocą automatycznego ekstraktora Dionex ASE 200 produkcji Dionex Corporation (Stany Zjednoczone). W badaniach wykorzystano metodę ekstrakcji opisaną przez Villagrasa i wsp. (2006), w której jako eluent zastosowano wodę destylowaną lub metanol (MeOH) zakwaszony $1 \%$ kwasem octowym. Ekstrakcje prowadzono w celach o pojemności $1 \mathrm{ml}$, pod ciśnieniem $102 \mathrm{MPa}$, stosując przepływ $60 \%$ pojemności celi. Jako solwentu użyto wody destylowanej oraz dwóch stężeń $\mathrm{MeOH}$ - 40 i 80\%.

\section{Eksperyment wazonowy}

Ocenę aktywności biologicznej wyciągów alkoholowych i wodnych uzyskanych z nawłoci późnej na produkcję biomasy przez mak polny przeprowadzono w latach 2015-2016. W tym celu wykonano doświadczenia w warunkach szklarniowych, stosując metodę kompletnej randomizacji i używając $w$ nich zmodyfikowanego biotestu I generacji (Sekutowski 2011). Ogółem wykonano trzy serie doświadczeń, każde w trzech powtórzeniach, w których jako akceptory wykorzystane zostały rośliny maku polnego ( $P$. rhoeas), natomiast naturalnym donorem były wyciągi alkoholowe $(40 \% \mathrm{MeOH}$ i $80 \% \mathrm{MeOH})$ i wodne uzyskane z suszu z części nadziemnych i podziemnych nawłoci późnej (S. gigantea).

Podłożem do wysiewu roślin testowych była uniwersalna mieszanka torfowo-mineralna o $\mathrm{pH} \mathrm{6,5} \mathrm{oraz} \mathrm{piasek}$ o średnicy $0,6-0,8 \mathrm{~mm} \mathrm{w}$ proporcji 2 : 1 . Po zmieszaniu tych składników napełniono podłożem doniczki, do których wysiewano nasiona maku polnego w ilości 8 sztuk. Po upływie 14 dni od wysiewu nasion, po wykiełkowaniu roślin wykonano ich przerywkę, pozostawiając w każdej doniczce po 5 roślin akceptorowych. Po kolejnych 7 dniach, gdy rośliny maku polnego osiągnęły zakładana fazę rozwojową - 11-12 w skali BBCH (Adamczewski i Matysiak 2005), czyli od 1. do 2. liści - wykonano opryskiwanie badanymi roztworami. W tabeli 1 . przedstawiono pełny schemat doświadczenia.

\section{Sporządzenie roztworów roboczych i ich aplikacja}

Do badań wykorzystano wyciągi alkoholowe (40\% $\mathrm{MeOH}$ i $80 \% \mathrm{MeOH})$ oraz wyciąg wodny, z których sporządzono roztwory robocze o stężeniu 5\% i 10\%. Przed użyciem otrzymane roztwory przesączano przez bibułę filtracyjną, uzyskując w ten sposób jednorodną ciecz roboczą. Jako rozpuszczalników używano samej wody destylowanej lub wody destylowanej $\mathrm{z}$ dodatkiem adiuwanta Atpolan Bio 80 EC w ilości odpowiadającej dawce 1,5 1/ha. Badany adiuwant zawiera w swoim składzie estry metylowe kwasów tłuszczowych oleju rzepakowego (80\%), substancje powierzchniowo czynne (surfaktanty) oraz bufor pH (20\%). Roztwory robocze do opryskiwania wykonano tuż przed samym zabiegiem. Opryskiwanie wykonano ze stałym ciśnieniem wynoszącym 0,25 MPa, w stacjonarnej komorze opryskowej „Aporo”, produkcji Przedsiębiorstwa Specjalistycznego Aporo Sp. z o.o. Wydatek cieczy roboczej odpowiadał 250 1/ha. Oceniając wpływ badanych roztworów na rośliny maku polnego, jako punkt odniesienia przyjęto obiekt kontrolny, na którym 
Tabela 1. Schemat doświadczenia

Table 1. Experimental design

\begin{tabular}{|c|c|c|c|}
\hline Obiekt - Treatment & $\begin{array}{c}\text { Stężenie roztworu } \\
\text { Concentration } \\
\text { of solution } \\
{[\%]}\end{array}$ & \multicolumn{2}{|c|}{ Rozpuszczalnik - Solvent } \\
\hline \multicolumn{4}{|c|}{ Nawłoć późna - wyciąg z korzeni i kłączy - Late goldenrod - extract from roots and rhizomes } \\
\hline Obiekt kontrolny - Untreated object & 0 & & - \\
\hline Wyciąg wodny - Water extract & 5 & \multirow{6}{*}{$\begin{array}{l}\text { woda destylowana } \\
\text { distilled water }\end{array}$} & \multirow{6}{*}{$\begin{array}{l}\text { woda destylowana + adiuwant } \\
\text { distilled water + adjuvant }\end{array}$} \\
\hline Wyciąg wodny - Water extract & 10 & & \\
\hline Wyciąg $40 \% \mathrm{MeOH}$ - Extract $40 \% \mathrm{MeOH}$ & 5 & & \\
\hline Wyciąg $40 \% \mathrm{MeOH}$ - Extract $40 \% \mathrm{MeOH}$ & 10 & & \\
\hline Wyciąg $80 \% \mathrm{MeOH}$ - Extract $80 \% \mathrm{MeOH}$ & 5 & & \\
\hline Wyciąg $80 \% \mathrm{MeOH}$ - Extract $80 \% \mathrm{MeOH}$ & 10 & & \\
\hline \multicolumn{4}{|c|}{ Nawłoć późna - wyciąg z łodyg i liści - Late goldenrod - extract from stalks and leaves } \\
\hline Obiekt kontrolny - Untreated object & 0 & & - \\
\hline Wyciąg wodny - Water extract & 5 & \multirow{6}{*}{$\begin{array}{l}\text { woda destylowana } \\
\text { distilled water }\end{array}$} & \multirow{6}{*}{$\begin{array}{l}\text { woda destylowana + adiuwant } \\
\text { distilled water + adjuvant }\end{array}$} \\
\hline Wyciąg wodny - Water extract & 10 & & \\
\hline Wyciąg $40 \% \mathrm{MeOH}$ - Extract $40 \% \mathrm{MeOH}$ & 5 & & \\
\hline Wyciąg $40 \% \mathrm{MeOH}$ - Extract $40 \% \mathrm{MeOH}$ & 10 & & \\
\hline Wyciąg $80 \% \mathrm{MeOH}$ - Extract $80 \% \mathrm{MeOH}$ & 5 & & \\
\hline Wyciąg $80 \% \mathrm{MeOH}$ - Extract $80 \% \mathrm{MeOH}$ & 10 & & \\
\hline
\end{tabular}

stosowano jedynie wodę destylowaną. Pozostałe badane obiekty traktowano 5 i $10 \%$ roztworami z wyciągów wodnych i alkoholowych uzyskanych z części nadziemnych i podziemnych nawłoci późnej.

Po wykonaniu opryskiwania, doniczki z roślinami umieszczono w laboratorium biologicznym w warunkach kontrolowanych, w temperaturze $25^{\circ} \mathrm{C}\left( \pm 1^{\circ} \mathrm{C}\right)$ i wilgotności $70 \%( \pm 5 \%)$. Po 28 dniach od momentu aplikacji badanych roztworów rośliny maku ścięto na wysokości szyjki korzeniowej i za pomocą wagi analitycznej określono ich świeżą masę. $\mathrm{Na}$ tej podstawie obliczano ubytek lub wzrost świeżej masy (w gramach) w porównaniu do roślin na obiekcie kontrolnym. Dla lepszego zobrazowania wyników otrzymane dane wyrażono również w procentach.

\section{Obliczenia statystyczne i nomenklatura}

W statystycznym opracowaniu wyników stosowano metody analizy wariancji dla doświadczeń w układzie kompletnej randomizacji. Istotność różnic testowano wykorzystując półprzedział ufności Tukeya, a najmniejszą istotną różnicę podano dla poziomu ufności wynoszącego 0,05 .

Nomenklaturę nazw chwastów opisywanych w niniejszej pracy podano za Flowering Plants and Pteridophytes of Poland a Checklist (Mirek i wsp. 2002).

\section{Wyniki i dyskusja / Results and discussion}

\section{Ocena aktywności wyciągów pozyskanych z części podziemnych}

W przypadku, gdy do sporządzenia roztworu roboczego wykorzystano wodę destylowaną obserwowano zróżnicowaną reakcję roślin. Aplikacja 5\% roztworu roboczego na bazie wyciągu wodnego oraz 5\% roztworu z $80 \%$ wyciągu alkoholowego nie miała żadnego wpływu na produktywność biomasy przez mak polny. Roztwór wykonany $\mathrm{z} 10 \%$ wyciągu wodnego ograniczał świeżą masę roślin o $12 \%$, podobnie działał $5 \%$ roztwór powstały z wyciągu $40 \% \mathrm{MeOH}$, który redukował biomasę maku o $18 \%$. Jednak różnice te okazały się nieistotne statystycznie. Stymulację wzrostu roślin o 12 i $24 \%$ obserwowano po aplikacji $10 \%$ roztworów roboczych powstałych z wyciągów 40\% i $80 \% \mathrm{MeOH}$. Również te różnice nie zostały potwierdzone statystycznie (tab. 2).

Odmiennie wygląda reakcja roślin maku polnego w przypadku, gdy do przygotowania roztworów roboczych użyto badanych wyciągów, które rozpuszczono w wodzie destylowanej z dodatkiem adiuwanta. W każdym przypadku obserwowano statystycznie istotną stymulację produkcji biomasy przez mak polny. Najsłabszą reakcję odnotowano po zastosowaniu roztworów powstałych z 5\% wyciągów z $80 \% \mathrm{MeOH}$ i wodnego. Produktywność biomasy była wyższa w porównaniu do obiektu kontrolnego odpowiednio o $388 \%$ i $476 \%$. Zastosowanie roztworów roboczych na bazie 5\% wyciągów z 40\% MeOH i 10\% z 80\% MeOH powodowało dalszą istotną stymulację produkcji świeżej masy przez rośliny maku polnego, o odpowiednio 541\% i 565\%. Najintensywniej rośliny badanego gatunku rosły, gdy zostały potraktowane $10 \%$ roztworami uzyskanymi z 40\% wyciągu $\mathrm{MeOH}$ i wyciągu wodnego. Ich biomasa była wyższa o $600 \%$ i $653 \%$ w porównaniu do obiektu kontrolnego (tab. 2).

\section{Ocena aktywności wyciągów pozyskanych z części nadziemnych}

Roztwory robocze, w których rozpuszczalnikiem była woda wykazały się niewielkim zróżnicowaniem działania 
Tabela 2. Aktywność biologiczna wyciągu alkoholowego i wodnego uzyskanego z korzeni i kłączy nawłoci późnej (Solidago gigantea) na produkcję biomasy przez mak polny (Papaver rhoeas)

Table 2. The biological activity of the alcoholic and water extracts from roots and rhizomes of late goldenrod (Solidago gigantea) on production of biomass by corn poppy (Papaver rhoeas)

\begin{tabular}{l|c|c|c|c}
\hline Obiekt - Treatment & $\begin{array}{c}\text { Stężenie roztworu } \\
\text { Concentration } \\
\text { of solution } \\
{[\%]}\end{array}$ & $\begin{array}{c}\text { Biomasa roślin } \\
\text { Biomass } \\
\text { of plants } \\
{[\mathrm{g}]}\end{array}$ & $\begin{array}{c}\text { Przyrost lub utrata } \\
\text { biomasy } \\
\text { Increase or loss } \\
\text { of biomass } \\
{[\%]}\end{array}$ & $\begin{array}{c}\text { Rodzaj } \\
\text { rozpuszczalnika } \\
\text { Solvent type }\end{array}$ \\
\hline Obiekt kontrolny - Untreated object & 0 & $16,3 \mathrm{a}$ & 0 & - \\
\hline Wyciąg wodny - Water extract & 5 & $16,3 \mathrm{a}$ & $12,3 \mathrm{a}$ & -12 \\
\hline Wyciąg wodny - Water extract & 10 & $13,4 \mathrm{a}$ & -18 & woda destylowana \\
distilled water
\end{tabular}

W kolumnie biomasa roślin [g] dane oznaczone tą samą literą należą do grupy jednorodnej i nie różnią się istotnie statystycznie pomiędzy sobą In the column biomass of plants [g] data denoted with the same letter belong to the homogeneous group and do not differ significantly between themselves

na rośliny maku polnego. Wystąpiła zarówno nieznaczna stymulacja, jak i hamowanie wzrostu. Ograniczenie biomasy maku o $24 \%$ wystąpiło po opryskiwaniu roślin $5 \%$ roztworem z wyciągu $40 \% \mathrm{MeOH}$. Podobny, lecz znacznie słabszy efekt (redukcja świeżej masy jedynie o 6\%) miał miejsce po użyciu $5 \%$ roztworu z $80 \% \mathrm{MeOH}$. Niewielka (o 6 i 12\%) stymulacja wzrostu maku polnego wystąpiła po zastosowaniu 5\% i 10\% roztworu z wyciągów wodnych z części nadziemnych nawłoci późnej. Również aplikacja $10 \%$ roztworów roboczych uzyskanych z wyciągów $40 \%$ i $80 \% \mathrm{MeOH}$ powodowała niewielką stymulację maku polnego do wzrostu, której skutkiem był przyrost biomasy o 6 i $29 \%$. Jednak w żadnym z powyższych przypadków analiza statystyczna nie potwierdziła istotności uzyskanych różnic (tab. 3).

Zdecydowanie intensywniej reagowały rośliny maku, gdy do sporządzenia roztworów roboczych jako rozpuszczalnika użyto wody destylowanej $\mathrm{z}$ dodatkiem adiuwanta. W każdym przypadku traktowane rośliny wytwarzały zdecydowanie więcej świeżej masy. Najmniejszy przyrost (o 382 do $459 \%$ ) wystąpił, gdy rośliny opryskiwano 5\% roztworami roboczymi powstałymi z wyciągu wodnego oraz wyciągów z 40\% i 80\% MeOH. Roztwór o stężeniu $10 \%$, sporządzony $\mathrm{z}$ wyciągu wodnego oraz uzyskany z wyciągu $80 \% \mathrm{MeOH}$ powodował stymulację wzrostu o 529-541\%, natomiast najsilniej reagowały rośliny po potraktowaniu ich $10 \%$ roztworem $\mathrm{z}$ wyciągu
40\% MeOH. W tym przypadku wytworzona przez nie biomasa była wyższa o $818 \%$ w porównaniu do obiektu kontrolnego. W każdym z tych przypadków różnice były statystycznie istotne (tab. 3).

$\mathrm{Z}$ informacji dostępnych w literaturze wynika, że gatunki z rodzaju Solidago mogą wywierać bardzo silny wpływ na inne gatunki roślin, które rosną w ich bliskim sąsiedztwie. Najczęściej będzie to działanie inhibicyjne, choć zdarzały się również przypadki stymulacji wzrostu (Yang i wsp. 2007; Tang i wsp. 2009; Zhang i wsp. 2009). Silne działanie nawłoci względem niektórych gatunków wynika z zawartości $\mathrm{w}$ ich komórkach metabolitów wtórnych, takich jak poliacetylany, diterpenoidy, saponiny, fenole, czy olejki eteryczne, które w sprzyjających warunkach środowiskowych mogą wykazywać właściwości allelochemiczne (Inose i wsp. 1991; Lu i wsp. 1993; Lu i wsp. 1995; Tori i wsp. 1999; Choi i wsp. 2004; Lendl i Reznicek 2007).

W badaniach Pisuli i Meinersa (2010) wykazano, że po zastosowaniu wyciągu wodnego $\mathrm{z}$ liści $S$. canadensis i S. gigantea obserwowano silne działanie inhibicyjne na wzrost Raphanus sativus. Również w badaniach przeprowadzonych przez Kiecia i Wieczorek (2009) dotyczących przydatności różnych wyciągów i wywarów do ograniczania biomasy Chenopodium album wynika, że większość z nich wykazuje działanie inhibicyjne. Podobne rezultaty osiągnęli Baličević i wsp. (2015). W ich badaniach wodne 
Tabela 3. Aktywność biologiczna wyciągu alkoholowego i wodnego uzyskanego z łodyg i liści nawłoci późnej (Solidago gigantea) na produkcję biomasy przez mak polny (Papaver rhoeas)

Table 3. The biological activity of the alcoholic and water extracts from stalks and leaves of late goldenrod (Solidago gigantea) on production of biomass by corn poppy (Papaver rhoeas)

\begin{tabular}{l|c|c|c|c}
\hline \multicolumn{1}{|c|}{ Obiekt - Treatment } & $\begin{array}{c}\text { Stężenie roztworu } \\
\text { Concentration } \\
\text { of solution } \\
{[\%]}\end{array}$ & $\begin{array}{c}\text { Biomasa roślin } \\
\text { Biomass } \\
\text { of plants } \\
{[\mathrm{g}]}\end{array}$ & $\begin{array}{c}\text { Przyrost lub utrata } \\
\text { biomasy } \\
\text { Increase or loss } \\
\text { of biomass } \\
{[\%]}\end{array}$ & $\begin{array}{c}\text { Rodzaj } \\
\text { rozpuszczalnika } \\
\text { Solvent type }\end{array}$ \\
\hline Obiekt kontrolny - Untreated object & 0 & $15,7 \mathrm{a}$ & 0 & - \\
\hline Wyciąg wodny - Water extract & 5 & $16,6 \mathrm{a}$ & +6 & +12 \\
\hline Wyciąg wodny - Water extract & 10 & $17,6 \mathrm{a}$ & -24 & woda destylowana \\
distilled water
\end{tabular}

W kolumnie biomasa roślin [g] dane oznaczone tą samą literą należą do grupy jednorodnej i nie różnią się istotnie statystycznie pomiędzy sobą In the column biomass of plants [g] data denoted with the same letter belong to the homogeneous group and do not differ significantly between themselves

wyciągi uzyskane z liści S. gigantea hamowały kiełkowanie nasion Amaranthus retroflexus, Daucus carota, Coriandrum sativum i Hordeum sativum. Według innych badań ekstrakty wodne uzyskane $\mathrm{z}$ nawłoci późnej również skutecznie ograniczały kiełkowanie oraz hamowały początkowy rozwój roślin pszenicy oraz maruny bezwonnej (Ravlić i wsp. 2015).

Metabolity wtórne zawarte w nawłociach oprócz działania na rośliny wykazały także aktywność w stosunku do grzybów i sinic. Liu i wsp. (2016) wykazali, że olejki eteryczne uzyskane z $S$. canadensis skutecznie hamowały rozwój grzyba Botrytis cinerea porażającego truskawki, zapewniając również ich lepsze przechowywanie. Huang i wsp. (2013) dowiedli, że ekstrakty alkoholowe z części nadziemnych $S$. canadensis hamowały rozwój sinic $\mathrm{z}$ gatunku Microcystis aeruginosa.

W literaturze obecne są również doniesienia o stymulującym wpływie wyciągów uzyskanych z różnych gatunków nawłoci na rozwój innych roślin. Jednak w żadnym przypadku nie uzyskano tak intensywnej stymulacji wzrostu, jak po zastosowaniu badanych przez autorów wyciągów $\mathrm{z}$ dodatkiem adiuwanta.

Bing-Yao i wsp. (2006) wykorzystując w swoich badaniach wodne oraz etanolowe wyciągi sporządzone z kłączy S. canadensis wykazali zwiększenie zdolności kiełkowania nasion Brassica napus var. napus. Z badań przeprowadzonych przez Baličević i wsp. (2015) wynika, że wodne wyciągi uzyskane $\mathrm{z}$ liści $S$. gigantea mogą stymulować siewki niektórych gatunków chwastów do szybszego wzrostu, np. A. theophrasti. W badaniach, jakie wykonali Grul'ová i wsp. (2016) ekstrakty metanolowe z dwóch gatunków nawłoci (S. canadensis i S. gigantea) powodowały istotny dodatni wpływ na wzrost elongacyjny rzodkwi i rzeżuchy zwyczajnej. W badaniach laboratoryjnych Affek-Starczewska i Rzymowska (2012) wykazały, że obecność nasion nawłoci w sąsiedztwie ziarniaków zbóż istotnie różnicowała długość korzeni i kiełków trzech gatunków zbóż (pszenicy, jęczmienia i owsa). Większe zagęszczenie ziarniaków nawłoci powodowało stymulację wzrostu tych roślin, co mogłoby świadczyć o allelopatycznych oddziaływaniach nawłoci.

\section{Wnioski / Conclusions}

1. Wyniki przeprowadzonych doświadczeń wykazały, że wyciągi uzyskane z nawłoci późnej ( $S$. gigantea) wykazują aktywność biologiczną w stosunku do roślin maku polnego (P. rhoeas).

2. Aktywność biologiczna wyciągów z nawłoci późnej zależała od rodzaju rozpuszczalnika oraz stężenia roztworu, natomiast niewielkie znaczenie miało to, z jakiej części rośliny pozyskano wyciągi.

3. Roztwory powstałe $\mathrm{z}$ rozcieńczenia badanych wyciągów wodą destylowaną powodowały zarówno stymulację (do 29\%), jak i ograniczenie (do 24\%) produkcji 
biomasy przez mak polny. Jednak uzyskane różnice w działaniu nie zostały udowodnione statystycznie.

4. Zdecydowanie silniejszym działaniem stymulującym wytwarzanie świeżej masy przez mak polny charakteryzowały się ekstrakty wodne i alkoholowe rozpuszczone $\mathrm{w}$ wodzie $\mathrm{z}$ dodatkiem adiuwanta. Traktowane nimi rośliny charakteryzowały się masą większą od $382 \%$ do $818 \%$, w porównaniu do roślin nieopryskiwanych, co zostało również potwierdzone statystycznie.

\section{Podziękowanie / Acknowledgements}

Praca wykonana w ramach projektu nr 2011/03/ /B/NZ9/04763, pt: "Ograniczanie występowania roślin inwazyjnych z rodzajów Solidago i Reynoutria z wykorzystaniem biomasy do pozyskiwania biologicznie czynnych metabolitów”, finansowanego przez Narodowe Centrum Nauki.

\section{Literatura / References}

Abilasha D., Quintana N., Vivanco J., Joshi J. 2008. Do allelopathic compounds in invasive Solidago canadensis s.I. restrain the native European flora? Journal of Ecology 96 (5): 993-1001. DOI: 10.1111/j.1365-2745.2008.01413.x.

Adamczewski K., Matysiak K. 2005. Klucz do określania faz rozwojowych roślin jedno- i dwuliściennych w skali BBCH. Instytut Ochrony Roślin, Państwowa Inspekcja Ochrony Roślin i Nasiennictwa, Główny Inspektorat, Poznań, 134 ss.

Affek-Starczewska A., Rzymowska Z. 2012. Kiełkowanie i początkowy wzrost trzech gatunków zbóż w obecności nasion Solidago canadensis L. [Assessment of germination and initial growth of three species of cereal in the presence of Solidago canadensis L. seed]. Zeszyty Naukowe Uniwersytetu Przyrodniczego we Wrocławiu - Rolnictwo 101 (585): 7-12.

Anwar S., Shah W.A., Shafi M., Bakht J., Khan M.A. 2003. Efficacy of sorgaab (sorghum water extract) and herbicide for weed control in wheat (Triticum aestivum L.) crop. Pakistan Journal of Weed Science Research 9 (3-4): 161-170.

Baličević R., Ravlić M., Živković T. 2015. Allelopathic effect of invasive species giant goldenrod (Solidago gigantea Ait.) on crops and weeds. Herbologia 15 (1): 19-29. DOI: 10.5644/Herb.15.1.03.

Bing-Yao S., Jian-Zhong T., Zhi-Gang W., Fu-Gen G., Ming-De Z. 2006. Allelopathic effects of extracts from Solidago canadensis L. against seed germination and seedling growth of some plants. Journal of Environmental Sciences 18 (2): 304-309.

Cheema Z., Farooq M., Khaliq A. 2013. Application of allelopathy in crop production: success story from Pakistan. p. 113-143. In: “Allelopathy” (Z. Cheema, M. Farooq, A. Wahid, eds.). Berlin Heidelberg Springer-Verlag Press.

Cheng F., Cheng Z. 2015. Research progress on the use of plant allelopathy in agriculture and the physiological and ecological mechanisms of allelopathy. Frontiers in Plant Science 6: 1020. DOI: 10.3389/fpls.2015.01020.

Choi S.Z., Choi S.U., Lee K.R. 2004. Phytochemical constituents of the aerial parts from Solidago virga-aurea var. gigantea. Archives of Pharmacal Research 27 (2): 164-168. DOI: https://doi.org/10.1007/BF02980100.

Dajdok Z., Pawlaczyk P. 2009. Inwazyjne gatunki roślin ekosystemów mokradłowych Polski. Klubu Przyrodników, Świebodzin, 167 ss.

Dajdok Z., Śliwiński M. 2009. Rośliny inwazyjne Dolnego Śląska. Polski Klub Ekologiczny - Okręg Dolnośląski, Wrocław, 64 ss.

Grul'ová D., Baranová B., Ivanova V., De Martino L., Mancini E., De Feo V. 2016. Composition and bio activity of essential oils of Solidago spp. and their impact on radish and garden cress. Allelopathy Journal 39 (2): 129-142.

Huang Y., Bai Y., Wang Y., Kong H. 2013. Allelopathic effects of the extracts from an invasive species Solidago canadensis L. on Microcystis aeruginosa. Letters in Applied Microbiology 57 (5): 451-458. DOI: 10.1111/lam.12133.

Inose Y., Mijyase T., Ueno A. 1991. Studies on the constituents of Solidago virga-aurea L. I. structural elucidation of saponins in the herb. Chemical and Pharmaceutical Bulletin 39 (8): 2037-2042. DOI: https://doi.org/10.1248/cpb.39.2037.

Khan M.A., Marwat K.B., Hassan G., Hussain Z. 2005. Bioherbicidal effects of tree extracts on seed germination and growth of crops and weeds. Pakistan Journal of Weed Science Research 11 (3-4): 89-94.

Kieć J., Wieczorek D. 2009. Badania nad przydatnością wyciągów i wywarów roślinnych do zwalczania komosy białej. [Investigation on aqeous plant extracts tested as biologically active factors used for weed control]. Progress in Plant Protection/Postępy w Ochronie Roślin 49 (1): 371-377.

Lendl A., Reznicek G. 2007. Two new saponins from Solidago gigantea. Scientia Pharmaceutica 75: 111-120.

Liu S., Shao X., Wei Y., Li Y., Xu F., Wang H. 2016. Solidago canadensis L. essential oil vapor effectively inhibits Botrytis cinerea growth and preserves postharvest quality of strawberry as a food model system. Frontiers in Microbiology 7: 1179. DOI: 10.3389/fmicb.2016.01179.

Lu T., Menelaou M.A., Vargas D., Fronczek F.R., Fisher N.H. 1993. Polyacetylenes and diterpenes from Solidago canadensis. Phytochemistry 32 (6): 1483-1488.

Lu T., Vargas D., Franzblau S., Fischer N.H. 1995. Diterpenes from Solidago rugosa. Phytochemistry 38 (2): 451-456.

Mirek Z., Piękoś-Mirkowa H., Zając A., Zając M. 2002. Flowering Plants and Pteridophytes of Poland - a Checklist. [Krytyczna lista roślin naczyniowych Polski]. PAN, Kraków, 442 ss.

Pisula N.L., Meiners S.J. 2010. Allelopathic effects of goldenrod species on turnover in successional communities. American Midland Naturalist 163 (1): 161-172.

Putnam A.R. 1988. Allelochemicals from plants as herbicides. Weed Technology 2: 510-518.

Ravlić M., Baličević R., Peharda A. 2015. Allelopathic effect of invasive species giant goldenrod (Solidago gigantea Ait.) on wheat and scentless mayweed. p. 186-190. 8th International Scientific Professional Conference Agricultural in Nature and Environment Protection. Vukovar Hrvatska, Vukovar, Croatia, 1st-3th June, 2015, 195 pp.

Rola J., Rola H. 2010. Solidago spp. biowskaźnikiem występowania odłogów na gruntach rolnych. [Solidago spp. as bioindicator of fallow occurence on arable area]. Fragmenta Agronomica 27 (3): 122-131.

Sekutowski T. 2011. Application of bioassays in studies on phytotoxic herbicide residues in the soil environment. p. 253-272. In: "Herbicides and Environment” (A. Kortekamp, ed.). InTech, Rijeka, Croatia, 746 pp.

Sekutowski T., Bortniak M., Domaradzki K. 2012. Ocena potencjału allelopatycznego rośliny inwazyjnej - nawłoci olbrzymiej (Solidago gigantea) w odniesieniu do gryki zwyczajnej (Fagopyrum sagittatum) oraz słonecznika zwyczajnego (Helianthus 
annuus). [Assessment of allelopathic potential of invasive plants - goldenrod (Solidago gigantea) on buchwheat (Fagopyrum sagittatum) and sunflower (Helianthus annuus)]. Journal of Research and Applications in Agricultural Engineering 57 (4): $86-91$.

Tang J., Zhang Q., Yang R., Chen X. 2009. Effects of exotic plant Solidago canadesis L. on local arbuscular mycorrhizal fungi. Bulletin of Science and Technology 25: 233-237.

Tokarska-Guzik B.E. 2005. The Establishment and Spread of Alien Plant Species (Kenophytes) in the Flora of Poland. Uniwersytet Śląski, Katowice, 192 pp.

Tokarska-Guzik B., Dajdok Z., Zając M., Zając A., Urbisz A., Danielewicz W., Hołdyński C. 2012. Rośliny obcego pochodzenia w Polsce ze szczególnym uwzględnieniem gatunków inwazyjnych. Generalna Dyrekcja Ochrony Środowiska, Warszawa, 197 ss.

Tori M., Katto A., Sono M. 1999. Nine new clerodane diterpenoids from rhizomes of Solidago altissima. Phytochemistry 52 (3): $487-493$.

Villagrasa M., Guillamon M., Eljarra E., Barcelo D. 2006. Determination of benzoxazinone derivatives in plants by combining pressurized liquid extraction-solid-phase extraction followed by liquid chromatography-electrospray mass spectrometry. Journal of Agricultural and Food Chemistry 54 (4): 1001-1008. DOI: 10.1021/jf050897p.

Yang R.Y., Mei L.X., Tang J.J., Chen X. 2007. Allelopathic effects of invasive Solidago canadensis L. on germination and growth of native Chinense plant species. Allelopathy Journal 19 (1): 241-248.

Zhang S., Jin Y., Tang J., Chen X. 2009. The invasive plant Solidago canadensis L. suppresses local soil pathogens through allelopathy. Applied Soil Ecology 41 (2): 215-222. DOI: https://doi.org/10.1016/j.apsoil.2008.11.002. 